\title{
11. Young People Creating the Future Today: Youth Development in the Pacific
}

\author{
Rose Maebiru
}

Les jeunes qui aujourd'hui créent l'avenir : L'évolution des jeunes dans le Pacifique

Quand il s'agit de l'évolution des jeunes, les pays du Pacifique ont besoin de changer de modèle. La période pendant laquelle on se tournait vers les sports et le divertissements en tant qu'activités en vue du développement de la jeunesse est révolue. Les questions des jeunes sont complexes et présentent de nombreux aspects; elles exigent une réflexion et des approches innovantes. Il faut considérer et traiter les jeunes et les problèmes de la jeunesse non pas comme une question d'aide sociale mais comme une question de développement national. Les secteurs public et privé peuvent tous les deux tirer des avantages s'ils impliquent les jeunes en tant que participants au développement du pays, et les jeunes ont quelque chose à apporter. La croissance annuelle de $2,2 \%$ prévue pour la population jeune dans la région exige de la créativité et de l'innovation dans les méthodes de travail avec les jeunes gens et les jeunes femmes pour surmonter des questions comme l'accès à une éducation de qualité pour tous, le chômage, les modes de vie et les comportements malsains, les conflits et la violence, les qualités de dirigeant, la participation à l'activité politique et l'inégalité des sexes. Cet article examine les stratégies adoptées par divers pays du Pacifique pour traiter du développement de leurs jeunes, en particulier les politiques nationales de la jeunesse en vue de donner des conseils et orienter le développement des jeunes. L'article se concentre sur le Plan Pacifique, sur la Stratégie de la jeunesse Pacifique 2010 et sur d'autres initiatives dédiées au développement des jeunes pour analyser les efforts des organisations régionales, des partenaires du développement, des donateurs et d'autres agences qui soutiennent le développement des jeunes qui tentent de reconnaître le besoin d'élargir les choix d'investissement dans le potentiel et le développement des jeunes comme ressource pour l'avenir et conclut que l'on peut faire davantage pour la jeunesse du Pacifique par le biais de partenariats efficaces et par la promotion d'une approche multisectorielle. 
Politics, Development and Security in Oceania

\section{From Issues to Policies and Action: Youth Development in the Pacific Region}

The projections of an annual growth rate of 2.2 per cent of the youth population in the region will continue to demand creative and innovative ways of working with young women and men to overcome issues of accessing integrated and quality education, unemployment, unhealthy lifestyles and behaviours, conflict and violence, leadership and participation, gender inequality to name a few.

The Pacific region has come a long way in its endeavours to unleashing the potential of young women and men to become leaders and custodians of our societies. With a mean age of 21 years for most Pacific island countries, the region has a huge resource at its disposal to address national and regional issues. However, for the most part, young people are viewed as 'problems' rather than solutions; a view that is detrimental to youth development itself.

Countries in the Pacific have embarked on several strategies to address the development of their young people, one of which is the development of national youth polices to provide guidance and direction for youth development. These 'paper commitments' often lack political will, resources and capacity to realise the policy goals and targets, fuelling discontent, alienation and a sense of hopelessness among young people. The frustrations of young people are evident in unfortunate events such as political and social upheavals that have occurred in some countries where young people were engaged in armed conflict, violence and other anti-social actions. These actions have drawn attention to the plight of young people in the context of national development and rebuilding. In more recent years more regional and international assistances are geared towards youth development, which is slowly putting more focus on addressing some of the institutional and structural weaknesses that hinder the implementation of the national youth policies. These efforts are slowly breaking the cycle of producing policies without actions. However, political will to support the expansion and sustainability of these changes is still minimal.

The development of national capacity to develop evidence based youth development policies and plans, implementation, coordination and monitoring are essential to ensuring that services and opportunities are equally and equitably accessed by young people in rural and urban areas. While these responsibilities fall within the mandate of the government, very little is being done to ensure that these capacities are built and supported. In some countries, the capacity does exist however, inadequate resources are allocated to utilise the opportunities. 
This next section briefly touches on a strategy that sets the stage for effective implementation of national and regional commitments and mandates, recognising that youth is not a sector but a cross-cutting matter that requires input from various sectors. This section also briefly highlights regional commitments and plans for youth development in the region by our leaders.

\section{Establishing Partnerships to Progress: Youth Development in the Pacific}

\section{Achieving More for Pacific Youth through Effective Partnerships and the Promotion of a Multi-sectoral Approach}

Regional organisations, development partners, donors and other agencies supporting youth development have recognised the need to widen options for investing in the potential and development of young people as a resource for the future. Youth development encompasses the inclusion of young people in all aspects of national development - economic, political, cultural and social - and requires an emphasis on developing young people so that they can fully participate in national efforts to increase economic growth, achieve good governance, maintain and improve security and stability and achieve sustainable development.

Investing in young people can draw long-term benefits for countries and territories in the Pacific region and is a less expensive option to addressing issues such as youth violence and crime, mental health, teenage pregnancy and HIV/STI infections which are a few of the growing and serious challenges facing young people in the Pacific today. Examples from the Caribbean region show that the region could increase its GDP by 1 per cent by lowering unemployment and by achieving higher enrolment in tertiary education, which could bring more than 2 per cent increase in the region's GDP growth as a result of the higher earning potential of university graduates on the labor market.

The Pacific region has not been able to generate such analysis, and solid research and analysis on the benefits of focused investment in youth development over the long term at both national and regional level can assist with bringing high level attention and resources to the table for progress. What is also clear is no single agency can support the full range of development options inclusive of programmes and services needed to ensure that young people are given the opportunity and experience to become responsible and productive individuals. A coordinated multi-sectoral approach can assist; based on sound evidence 
Politics, Development and Security in Oceania

and analysis that involves countries and agencies in a collaborative planning, implementation and monitoring process. This process should cover and involve: social services, sports and creative arts agencies, educational institutions, representatives of the employment sector, health service providers, private and public sectors agencies, policymakers, communities and young people.

\section{The Pacific Plan, Pacific Youth Strategy 2010 and Youth Development Initiatives}

Youth development is a strategic objective of the Pacific Plan and the Pacific Youth Strategy 2010 provides a solid framework on which to develop and mobilise multi-sectoral support for the development of young people at both national and regional level. However, limited available resources, weak economies and competing national and regional priorities; together with the huge challenge of promoting ownership and progressing coordination in the youth sector has hampered efforts to progress these youth commitments. At the same time, PICTs' young populations continue to grow putting pressure on already inadequate and weak services and the challenges mentioned earlier continue to expand. Current commitments and efforts need to be re-examined, consolidated with renewed approaches tried and resources up-scaled.

\section{Pacific Plan Initiatives:}

\section{Initiative 9.1: Enhance Advocacy for and Coordination of Youth Programmes and Monitor the Status of Youth}

This refers to the implementation of the Pacific Youth Strategy 2010 which was designed to promote, coordinate and monitor youth development in the region. Currently, SPC is conducting a review of the strategy in partnership with UNICEF Pacific and in consultation with other development partners, donors, financing institutions and SPC member countries and territories. This review and consultative process will contribute to the development of the next Pacific Youth Strategy which this time round will aim for stronger regional and country ownership; provide a solid framework on which to base a multi-sectoral strategy and implementation plan will require coordination, collaboration and joint approaches and programmes - both at regional and national level. This time round it is hoped that the emphasis on consultation and country and development partner ownership will result in more support and resources being directed to implementation. 
Initiative 15.4: Establish Volunteer Schemes and Other Forms of Regional Exchanges and Sharing of Services and Expertise for Regional Capacity Building

There is huge capacity to implement this initiative both in country but in particular across the region as there are many good examples of innovative and sustainable youth development programmes that can be shared and duplicated through a structured multi-sectoral approach and increased resources. A proposal that was designed by the SPC's Human Development Programme as part of this initiative is the Pacific Regional Volunteer Scheme. The scheme was designed in consultation with member countries and other regional youth agencies in 2005/2005; however it has not been implemented due to a lack of financial commitment and resources. The main purpose and objectives of the scheme are: contribute to building the skills of young people in the Pacific, provide career related opportunities and sharing of services and expertise regionally. The expected impact over the long term is to have skills exchange and skills development opportunities for young Pacific Islanders and promoting regional cooperation and integration.

\section{Pacific Youth Strategy 2010}

As mentioned above, the Pacific Youth Strategy 2010 was endorsed by Youth Ministers in 2005 and was recognised as the regional road map for youth development. Like other regional strategies, this strategy will remain a paper commitment if there are no resources and support for its implementation. The results of the review of this strategy will reveal the gaps, challenges and success stories, which will help to shape the future youth development strategies.

\section{Conclusion}

Countries in the Pacific need a paradigm shift when it comes to addressing youth development. Gone are the days when we look at sports and entertainment as youth development activities. Youth issues are complex and multi-facet and require innovative thinking and approaches. Youth and youth issues need to be addressed as a national development matter and not merely as a welfare issue. Both private and public sectors can benefit from involving young people as contributors to national development and young people have something to offer. Youth development is a win-win situation. 